\title{
Environmental and Ecosystem Services, Tree Diversity and Knowledge of Family Farmers
}

\author{
Gustavo Crizel Gomes ${ }^{1}$ (D), João Carlos Costa Gomes² (D), Rosa Lia Barbieri² (D), \\ Adalberto Koiti Miura $^{2}$ (D), Letícia Penno de Sousa ${ }^{2}$ \\ ${ }^{1}$ Universidade Federal de Pelotas - UFPel, Pelotas/RS, Brasil \\ ${ }^{2}$ Centro de Pesquisa Agropecuária de Clima Temperado, Empresa Brasileira de Pesquisa Agropecuária - EMBRAPA, \\ Pelotas/RS, Brasil
}

\begin{abstract}
The objective of this work is to identify environmental and ecosystem services provided by trees from the perception of family farmers in the Serra dos Tapes, southern Rio Grande do Sul, Brazil, addressing the relevance of species for ecosystem sustainability of family farming. Environmental and ecosystem services offered by the tree flora of semi-deciduous submontane forest are presented according to the perception of farmers who use accumulated knowledge for social, cultural and economic reproduction in family farming. Four farmers were selected for their remarkable knowledge related to the agro-ecosystem and the local floristic composition, and they answered semi-structured interviews about 115 native tree species relating them to environmental and ecosystem services. The knowledge of farmers regarding the importance of forest cover for beekeeping, agroforestry system installation, source of biological materials for environmental recovery, conservation of hydric resources and for feeding mammals and birds was evidenced.
\end{abstract}

Keywords: ethnobotany, ethno-knowledge, native trees, environmental preservation. 


\section{INTRODUCTION}

The identification of species of local biodiversity and the knowledge of their potential are important tools in the process of nature appropriation by social groups. Trees not only play a key role for their wood (Almeida, 2000), but also for the many products and services offered, some of increasing relevance to sustainability in its multiple dimensions (Martinez et al., 2013; Wolff \& Gomes, 2015). From the environmental point of view, trees present in riparian forests, on slopes, springs, and hilltops, and portions of the landscape referred to as Permanent Preservation Areas (APPs - Áreas de Preservação Permanente) sustain the most important resources for the productivity and sustainability of agroecosystems: water, soil, and biodiversity. With a few exceptions, these areas are preserved by family farmers in recognition of the environmental services they provide (indirect use value), even though the farmer is often unaware of the owner's legal responsibilities over APPs imposed by the Brazilian Forest Code (Almeida, 2000), and the consequences that change can have on the fauna, including key groups for the provision of environmental services such as mammals (Galetti et al., 2010), birds (Develey \& Pongiluppi, 2010) or bees (Imperatriz-Fonseca \& Nunes-Silva, 2010).

The attribution of direct use values to the species generates a notion of economic importance (self-consumption and surplus commercialization) so of them many are preserved, reproduced or managed in a sustainable way by cutting the wood without eliminating the tree, by regrowth management or through producing and reintroducing seedlings of the most used species.

Another way to benefit from the forest without compromising it is through the rational extraction of fruits, leaves, bark or fibers for the most diverse purposes (Simões \& Lino, 2002; Rodrigues et al., 2007; Elias \& Santos, 2016). When populations of certain species are preserved because of their direct uses (socio-economic dimension), the environmental services they carry out (environmental dimension) such as climate regulation and the maintenance of biogeochemical cycles (Kangas, 1997) or erosion control and the maintenance of water resources are also often maintained. In the literature on benefits of forest species, the use of the "environmental services" concept is more common, which in turn is defined in various ways and identified as either ecosystem services or ecological services. Despite the conceptual differences, all three terms are usually implied to designate the same processes (Whately \& Hercowitz, 2008). However, some authors have reservations and point out differences between these definitions.

A partnership between several international institutions was carried out between 2001 and 2005 with the support of several governments called "the Millennium Ecosystem Assessment", with the objective of providing scientific bases for the sustainable management of ecosystems. Ecosystem functions and services were classified into: provisioning services (or supply services) - food, water, wood for fuel, fibers, biochemistry, genetic resources; regulating services - climate regulation, disease regulation, biological regulation, water regulation and purification, regulation of natural damages and pollination; cultural services - ecotourism and recreation, spiritual and religious, aesthetic and inspirational, educational, sense of orientation, and cultural heritage; and supporting services - soil formation, oxygen production, nutrient cycling, primary production (Andrade $\&$ Romeiro, 2009).

For other authors, environmental services are "aspects of ecosystems actively or passively used to produce human well-being." They reinforce the need for a consistent definition from the ecological point of view, as "[...] ecosystem services are a function of complex interactions between species and their abiotic environment, use and usage of complex patterns and different perceptions by the beneficiaries" (Rodrigues et al., 2012, p. 13).

Environmental services are related to the benefits perceived by humans and conditioned to human activities and benefits. On the other hand, ecosystem services are more related "to the processes by which the environment produces resources that we usually perceive as "gifts" from nature, such as clean water, wood, habitat for fish and pollination of native or agricultural plants" (Whately \& Hercowitz, 2008). Along the same line of thought, Tôsto et al. (2012) consider that environmental services represent generated benefits and are associated with human management actions in natural and agricultural ecosystems, while ecosystem services only reflect direct and indirect benefits provided by the functioning of ecosystems, 
without human interference. Both concepts are used in this article to designate different processes. Thus "environmental service" represents direct benefits obtained by the product of human interference, such as beekeeping. "Ecosystem service" is used for indirect benefits without human interference, such as pollination. This study was carried out with the objective of identifying environmental and ecosystem services offered by the arboreal flora according to the perception of family farmers.

\section{MATERIAL AND METHODS}

\subsection{Study scope region}

The study area corresponds to the southern boundary of the Atlantic Forest Domains (Teixeira et al., 1986) in southeast Rio Grande do Sul, on the eastern slope of the Sul-Rio-Grandense Plateau, more precisely in the southern half of the Southeast Ridge (physiographic region), located between the Camaquã and Piratini rivers (Figure 1). The region is known as Serra dos Tapes in reference to the indigenous group that lived there. It houses remnants of the highly endangered Submontane Semi-deciduous Seasonal Forest, which once practically covered the whole region.

The occupation of this area began in 1857 with the Pomeranian colonization in São Lourenço do Sul, and it is currently fully exploited with a predominance of tobacco, corn, soybeans, beans, fruits (mainly peaches) and pasture areas, mostly in small farms (Teixeira et al., 1986). Important features of this region are the expressive presence of family agriculture (the municipality of Canguçu receives the title of "national capital of family agriculture" due to the large number of small rural farms) (Vieira et al., 2011), the marked ethnic and cultural diversity (descendants of indigenous, Pomeranian, Portuguese, Italian and French immigrants, besides Quilombola communities, and a mix of all these ethnic groups coexist in the region), and the fact that the remaining fragments of Semi-deciduous Seasonal Forest occur almost exclusively in family agro-ecosystems, land between one and four fiscal modules, which is 16 ha for all the municipalities that compose the Serra dos Tapes (INCRA, 1980; Vieira et al., 2011; Gomes, 2014).

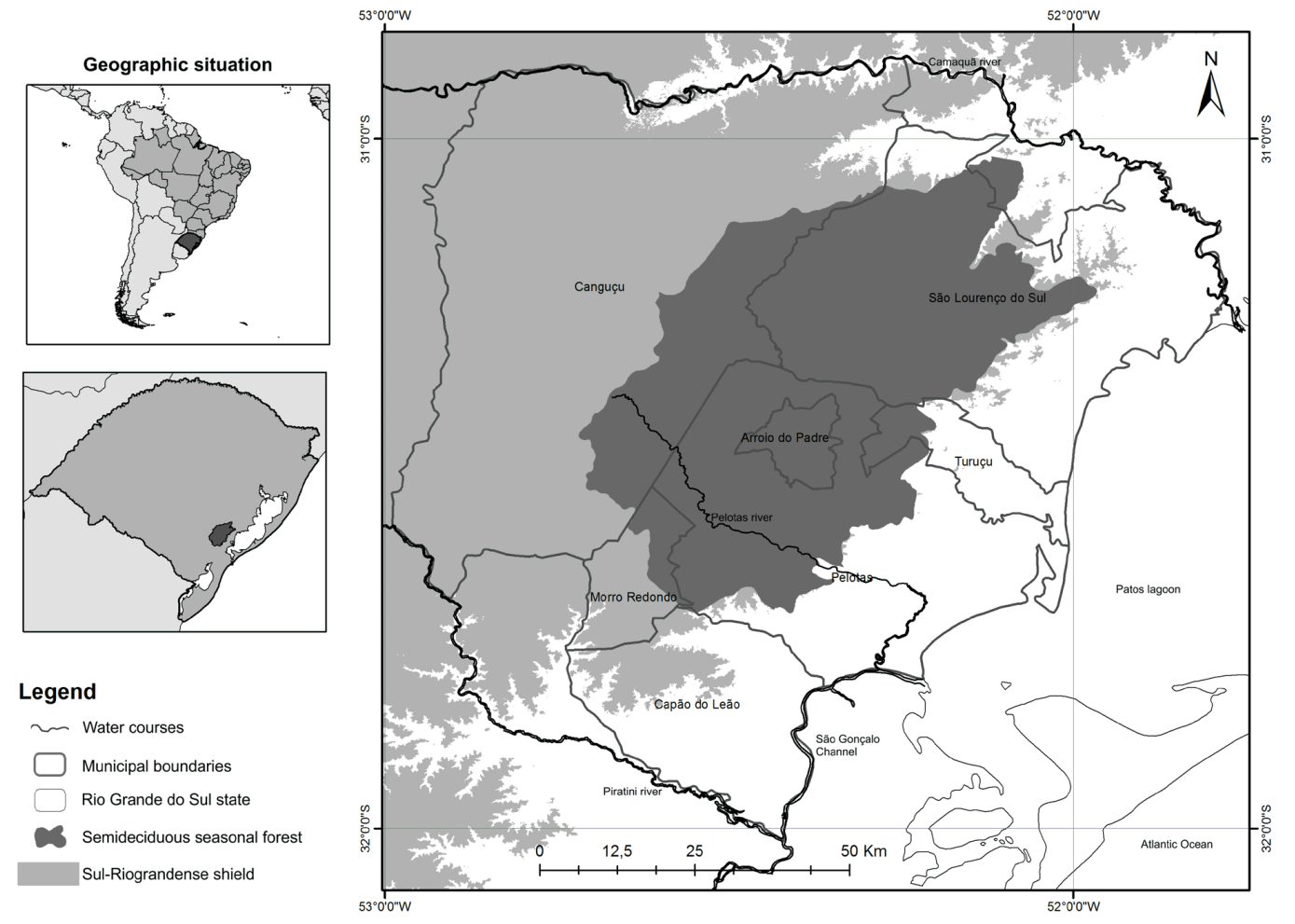

Figure 1. Location of Serra dos Tapes on the map of Rio Grande do Sul/Brazil. 
Recent studies point out the important role of family farmers in preserving and qualifying the biodiversity of the region (Reichert \& Gomes, 2013; Barbieri et al., 2014), including the provision of environmental services (Martinez et al., 2013).

\subsection{Social research methodologies and ethnobotany}

The snowball method was applied (Bernard, 2011) to identify key informants and to assess their knowledge of native tree diversity associated with key environmental and ecosystem services, initiated by technicians and local movement leaders of the family farmers ("seeds"), resulting in a total of ten family farmers. They were located and contacted for a pre-screening interview, in which four farmers of recognized knowledge about the regional tree flora and their uses expressed knowledge on the subject and showed full interest in participating in the research, and then, they were interviewed. Semi-structured interviews were carried out (Manzini, 2004) between January and March 2014, in which a previous script guided by some key questions was implemented, however giving the informants freedom to go over the subjects at their will. The interviews lasted from 14 to 18 hours and were carried out in blocks with a maximum duration of four hours. All interviews were recorded on a digital recorder.

\subsection{Characterization of informants and the interview script}

A brief description of their life history was requested from the informants, suggesting some questions and clarifying them to express only information that they wished. The script to identify environmental and ecosystem services associated with each tree species was composed of the following questions: Regarding management: a) Do you practice or know of any management practices involving this species, including monoculture, intercropping, and manufacture of agricultural products, extractivism, production, reintroduction or relocation of the seedlings or any others? Regarding the environmental importance: b) Do you know if the species provides any specific environmental service (food and shelter for species of fauna, retention of soil erosion, preservation of water resources). The informants were also asked to discuss the importance of tree species in the daily life of their agro-ecosystems.

The ethical principles according to the legislation for ethnobotanical and ethnoecological research that deals with the access to genetic heritage, protection and the access to associated traditional knowledge were respected during the study (Brasil, 2015), as well as the guidance on the need for prior participants' agreement to use the information provided in the research through signing of a Clear and Informed Consent Form (ICF) (Brasil, 1996). All farmers interviewed were clarified about the objectives of the study and they agreed to participate, to have their speeches recorded, and to allow publication of the information and they signed the ICF. The anonymity of the informants was guaranteed, and the information provided by them is associated with numbers (Informants 1-4) in the results.

\subsection{Inclusion of species and identification material for the interviews}

The tree species identified by Gomes (2009) were initially considered in this study. A bibliographic review of other studies considering the arboreal flora in the limits of Serra dos Tapes was carried out to complement the initial list (Souza, 2001; Jurinitz, 2002; Kilca, 2002; Venzke, 2012; Sobral et al., 2006). Surveys of the native tree flora in the interviewed farmers' ecosystems were also carried out. In the surveys on the farms, the walking methodology and curve of the collector method were used (Filgueiras et al., 1994). These efforts were performed by the authors without the participation of informants, and resulted in a total of 115 species included in this study, which were photographed in situ with records of the biological form (tree), trunk, leaves, flowers and fruits, as well as important vegetative traits for traditional identification by farmers such as thorns and exudations. Also, exsiccates/types of all the species were made. This material (photographs and exsicatas/types) previously elaborated by the authors was used in the interviews to ensure the correct identification of the species by the informants (Gomes, 2014), and presented in alphabetical order of families (APG IV, 2016) and species (Gomes, 2014).

Guided tours for in loco observation (Albuquerque et al., 2010) were performed only when necessary for some taxonomic confirmation of the species in the forest fragments of each farm. The informants were also 
questioned during the interviews whether there were any native species that were not included in the material used in the interviews.

Each species was numbered from 01 to 115 according to their organization in alphabetical order of families and species for presenting the results and in the tables. For the identification of animal species, those mentioned by their popular names (in Brazil/Portuguese) were recorded by the interviewees, which correlated them with the arboreal species in question (frugivory/dispersion for birds and mammals and visitation/pollination in the case of insects). A "re-identification" of the animals was carried out at a later moment with the aid of photographs and illustrated field guides (Belton, 2004; Azpiroz, 2012; Roman et al., 2013; Gonçalves et al., 2014), seeking to ensure the correct scientific zoological nomenclature.

\subsection{Classification of the species in relation to environmental and ecosystem services}

Establishing relevance criteria for the environmental and ecosystem services obeyed the number of citations by the interviewees. Thus, a citation of a service by two interviewees was considered as "medium relevance", and the criterion used was of "high relevance" when the citation happened among three and four farmers. For the scope of this study, the information was disregarded when it was reported by only one interviewee, considering that classifications are always arbitrary, although necessary (Cavalcanti, 2010). Mikhailova \& Barbosa (2004) declare the existence of challenges related to valuation of ecosystems and natural capital: identifying ecological services based on the characteristics of the study area, adequate methods for their evaluation and perception of the local actors, since in many cases, environmental, ecological or ecosystem services are perceived indirectly. Thus, some results will be shown preserving the participant's speeches to balance methodological classifications and the farmers' perceptions.

\section{RESULTS AND DISCUSSION}

Informant 1: A 51-year-old male. He reported that his father was Italian and his mother was German. The farmer says with pride: "I only studied until the fourth grade of primary school, and I managed the work at the farm to support my two children until they graduated". The farmer produces food for ecologically based systems and agroforestry systems (SAFs), he also extracts yerba mate/erva-mate, processed in the agro-ecosystem.

Informant 2: A 73-year-old male, an ecologically based family farmer, who says he has "[...] three types of blood in his veins", referring to his ancestors of Italian, Spanish and German origin. He has always used forest resources for various purposes, including for food, herbal medicines, energy, construction, tool making, and others.

Informant 3: A 63-year-old male. He claims: "I'm kind of bugre", referring to his indigenous origin. He has resided in eight locations in the Serra dos Tapes, performing several activities:

I've worked in the fields, taking care of the land, I've been a blacksmith, I've been a tamer... I've been a cowboy, I made laces, straps... I've been a fence maker, I have made houses using santa-fé [a native grass], mud and local woods." His relationship with biodiversity is very strong: "Back then we depended on the woods to survive.

Informant 4: A 53-year-old male, he says “[... a mixture of German and Italian". He lives on the propriety where he was born and worked with his parents in a sawmill and doing carpentry, according to him: "We used to make ox carts and wagons in carpentry, using only native wood. The eucalyptus only arrived much later". In addition to the agricultural production based on agroforestry, nowadays he also runs a vegetarian restaurant on the farm.

Only 17 of the 115 tree species presented were not recognized by the interviewees; 14 of them were not related to environmental or ecosystem services, although they have been mentioned for other functions (medicinal, use for tools or improvements on the farm such as houses, sheds, for the construction of doors, windows, carts, etc.). The other two were not recognized by their popular names (in Brazilian Portuguese), although the farmers attributed usages to them. Table 1 lists the species grouped by families according to the common/popular names (in Brazilian Portuguese) assigned to them by the farmers. Some species (and their respective numbers) are not listed in the tables or text because they were not cited in relation to environmental and ecosystem services by any respondent. Although some species have been cited by more than one name, only those with 
Table 1. List of tree species cited by the farmers in the Serra dos Tapes (RS) related to environmental and ecosystem services.

\begin{tabular}{|c|c|c|c|}
\hline & Family & Scientific name & Popular name \\
\hline 1 & Adoxaceae & Sambucus australis Cham. \& Schlecht. & Sabugueiro \\
\hline 2 & Anacardiaceae & Lithrea brasiliensis Marchand & Aroeira-preta \\
\hline 4 & Anacardiaceae & Schinus molle L. & Aroeira-piriquita \\
\hline 5 & Anacardiaceae & Schinus polygama (Cav.) Cabrera & Pipinha, molho \\
\hline 6 & Anacardiaceae & Schinus terebinthifolia Raddi. & Aroeira-mansa \\
\hline 8 & Annonaceae & Annona sylvatica A. St.-Hil. & Araticum \\
\hline 13 & Araucariaceae & Araucaria angustifolia (Bertol.) Kuntze. & Araucária \\
\hline 14 & Arecaceae & Syagrus romanzoffiana (Cham.) Glassman & Jerivá \\
\hline 16 & Asteraceae & Moquiniastrum polymorphum (Less.) G. Sancho & Cambará \\
\hline 19 & Cactaceae & Cereus hildmannianus K. Schum & Tuna \\
\hline 20 & Cannabaceae & Celtis iguanaea (Jacq.) Sarg. & Taleira \\
\hline 21 & Cannabaceae & Trema micrantha (L.) Blume. & Pau-de-vaca \\
\hline 27 & Combretaceae & Terminalia australis Cambess. & Sarandi \\
\hline 28 & Ebenaceae & Diospyros inconstans Jacq. & Maria-preta \\
\hline 30 & Erythroxylaceae & Erythroxylum argentinum O. E. Schulz. & Cocão \\
\hline 31 & Escalloniaceae & Escallonia bifida Link e Otto. & Cana-de-pito \\
\hline 35 & Euphorbiaceae & Manihot grahamii Hook. & Mandioca-brava \\
\hline 36 & Euphorbiaceae & Sapium glandulosum (L.) Morong & Pau-leiteiro, leiteiro \\
\hline 38 & Euphorbiaceae & Gymnanthes klotzschiana Müll. Arg. & Branquilho \\
\hline 41 & Fabaceae & Bauhinia forficata Link. & Pata-de-vaca \\
\hline 42 & Fabaceae & Calliandra tweedii Benth. & Quebra-foice \\
\hline 43 & Fabaceae & Erythrina cristagalli $\mathrm{L}$. & Corticeira \\
\hline 47 & Fabaceae & Senna corymbosa (Lam.) H.S.Irwin \& Barneby & Fedegoso \\
\hline 48 & Lamiaceae & Vitex megapotamica (Spreng.) Moldenke. & Tarumã-branco \\
\hline 49 & Lamiaceae & Nectandra megapotamica (Spreng.) Mez. & Canela-merda \\
\hline 50 & Lauraceae & Ocotea puberula (Rich.) Nees & Canela-sebo \\
\hline 52 & Lauraceae & Luehea divaricata Mart. \& Zucc. & Açoita-cavalo \\
\hline 53 & Melastomataceae & Miconia hyemalis A.St.-Hil. \& Naudin & Falsa-pixirica \\
\hline 54 & Melastomataceae & Miconia pusilliflora (DC.) Naudin & Pixirica \\
\hline 55 & Meliaceae & Cabralea canjerana (Vell.) Mart. & Canjerana \\
\hline 56 & Meliaceae & Cedrela fissilisVell. & Cedro \\
\hline 59 & Moraceae & Ficus cestrifolia Schott ex Spreng. & Figueira-folha-fina \\
\hline 60 & Moraceae & Ficus luschnathiana (Miq.) Miq. & Figueira-folha-larga \\
\hline 61 & Moraceae & Sorocea bonplandii (Baill.) W.C. Burger et al. & Chincho \\
\hline 63 & Myrtaceae & Blepharocalyx salicifolius (Kunth) O. Berg & Murta \\
\hline 64 & Myrtaceae & Campomanesia xanthocarpa O.Berg & Guabiroba \\
\hline 65 & Myrtaceae & Eugenia involucrata DC. & Cereja-do-mato \\
\hline 67 & Myrtaceae & Eugenia uniflora L. & Pitanga \\
\hline 68 & Myrtaceae & Eugenia uruguayensis Cambess. & Cambuí \\
\hline 73 & Myrtaceae & Myrcianthes pungens (O.Berg) D. Legrand. & Guabiju \\
\hline 74 & Myrtaceae & Myrrhinium atropurpureum Schott & Pau-ferro \\
\hline 75 & Myrtaceae & Psidium cattleianum Sabine & Araçá \\
\hline 79 & Podocarpaceae & Podocarpus lambertii Klotzsch ex Endl. & Pinheiro-manso \\
\hline 82 & Primulaceae & Myrsine coriacea (Sw.) R.Br. ex Roem. \& Schult. & Capororoca \\
\hline 84 & Primulaceae & Myrsine umbellata Mart. & Capororoca \\
\hline 85 & Quillajaceae & Quillaja brasiliensis (A.St.-Hil. e Tul.) Mart. & Timbaúva \\
\hline 87 & Rhamnaceae & Scutia buxifolia Reissek. & Corunilha \\
\hline 92 & Rutaceae & Zanthoxylum fagara (L.) Sarg. & Coentrilho \\
\hline 93 & Rutaceae & Zanthoxylum rhoifolium Lam. & Teta-de-cadela \\
\hline
\end{tabular}


Table 1. Continued...

\begin{tabular}{cllc} 
& Family & \multicolumn{1}{c}{ Scientific name } & Popular name \\
\hline 94 & Salicaceae & Banara parviflora (A. Gray) Benth. & Guaçatunga \\
96 & Salicaceae & Casearia decandra Jacq. & Guaçatumba \\
97 & Salicaceae & Casearia sylvestris Sw. & Bugrinho \\
98 & Salicaceae & Salix humboldtiana Willd & Salso \\
\hline 100 & Sapindaceae & Allophylus edulis (A.St.-Hil et al.) Hieron ex Niederl & Chale-chale \\
101 & Sapindaceae & Cupania vernalis Cambess. Radlk. & Camboatá \\
103 & Sapindaceae & Matayba elaeagnoides Radlk. & Camboatá-branco \\
105 & Sapotaceae & Chrysophyllum marginatum (Hook. e Arn.) Radlk. & Carne-de-vaca \\
106 & Sapotaceae & Pouteria salicifolia (Spreng.) Radlk. & Mata-olho \\
107 & Solanaceae & Solanum mauritianum Scop. & Fumo-bravo \\
109 & Solanaceae & Vassobia breviflora (Sendtn.) Hunz. & Espora-de-galo \\
\hline 114 & Verbenaceae & Citharexylum montevidense (Spreng.) Moldenke & Tarumã-de-espinho \\
\hline
\end{tabular}

a higher occurrence among those interviewed were used (the name maintained was the one that received the most mentions). A great confluence in the forms of recognition, morphological aspects, forms of use, relevance as providers of environmental services and cultural preservation were observed. Differences were found between the number of species recognized by the interviewees when comparing the presented material and the accumulated knowledge about the tree flora of Serra dos Tapes; while one respondent recognized 97 species, another only recognized 64 species.

Regarding ecosystem services, 68 species were cited as being important for food for the fauna (mammals and birds), 21 were considered of medium relevance, and 20 of high relevance (Table 2). This relationship is fundamental for the survival and renewal of native forests, establishing a kind of double-exchange process, where the forests provide food, and birds and other components of the fauna are responsible for seed dispersal. According to the farmers, the beneficiary birds are: Jacu - Penelope obscura Temminck, 1815; Jacutinga - Ortalis squamata (Lesson, 1829); Gralha-azul - Cyanocorax caeruleus (Vieillot, 1818); Tucano-de-bico-verde - Ramphastos dicolorus (Linnaeus, 1766); Tucano-toco - Ramphastos toco Statius Muller, 1776; Pomba-picuí - Columbina picui (Temminck, 1813); Pomba-de-bando - Zenaida auriculata (Des Murs, 1847); Pombinha-juriti - Leptotila verreauxi Bonaparte, 1855; Saíra - Tangara preciosa (Cabanis, 1850); Periquito - Pyrrhura frontalis (Vieillot, 1817); Papa-laranja - Pipraeidea bonariensis (Gmelin, 1789); Caturrita - Myiopsitta monachus (Boddaert, 1783); Calandra - Mimus saturninus (Lichtenstein, 1823); Sabiá-de-coleira - Turdus albicollis Vieillot, 1818; Sabiá-poca - (Turdus. amaurochalinus Cabanis, 1850;
Sabiá-laranjeira - Turdus rufiventris Vieillot, 1818; Pombão-carijó - Patagioenas picazuro (Temminck, 1813). The Papagaio-charão - Amazona pretrei (Temminck, 1830), now extinct in the region, was mentioned by informant 1 as being the main appreciator of murta fruits (Blepharocalyx salicifolius): "during the fruit season the parrot's flesh tasted like murta!".

Also according to the farmers' observations, the mammals benefited are: Cachorro-do-mato - Cerdocyon thous (Linnaeus, 1766); Ouriço - Sphiggurus villosus (F. Cuvier, 1823); Paca - Cuniculus paca (Linnaeus, 1766); Gambá - Didelphis albiventris Lund, 1840; Tatu-galinha - Dasypus novemcinctus Linnaeus, 1758; and bats (Mammalia, Chiroptera). The Jundiá fish was also cited - Rhamdia quelen (Quoy \& Gaimard, 1824).

It is worth pointing out the number of tree species important for pollinators; 50 were reported as being beneficial trees for bees (Apidae), including native stingless bee (Meliponini), wasps (Vespidae), bats and other pollinators, of which 15 were classified as medium relevance and eight as high relevance. Nine (9) trees were cited as important to bees and native wasps (Table 3 ).

The Hymenoptera mentioned in the interviews were: Abelha-europeia-africanizada - Apis melifera Linnaeus, 1758; Irapuá - Trigona spinipes (Fabricius, 1793); Tibuna - Scaptotrigona bipunctata (Lepeletier, 1836); Miruim - Plebeia sp.; Mamangavas - Bombus spp.; Camoatin - Polybia scutellaris (Write, 1841); and Lixiguana - Brachygastra lecheguana (Latreille, 1824). In this case, environmental and ecosystem services are simultaneous. According to Andrade \& Romeiro (2009), the "[...] ecosystem functions related to plant reproduction, such as pollination are also translated 
Table 2. Relevance of tree species and ecosystem services for fauna in Serra dos Tapes (RS) according to interviewed farmers.

\begin{tabular}{|c|c|c|c|c|}
\hline & Family & Scientific name & Relevance & Related Fauna \\
\hline 1 & Adoxaceae & Sambucus australis & M & Turdus spp. \\
\hline 2 & Anacardiaceae & Lithrea brasiliensis & $\mathrm{H}$ & Pyrrhura frontalis \\
\hline 4 & Anacardiaceae & Schinus molle & M & P. frontalis \\
\hline 5 & Anacardiaceae & Schinus polygamus & M & Birds (no specific mention) \\
\hline 6 & Anacardiaceae & Schinus terebinthifolia & $\mathrm{H}$ & Turdus spp., Tangara preciosa \\
\hline 8 & Annonaceae & Annona sylvatica & M & Cuniculus paca, Didelphis albiventris, \\
\hline 13 & Araucariaceae & Araucaria angustifolia & M & $\begin{array}{l}\text { Cyanocorax caeruleus, Myiopsitta monachus, } \\
\text { C. paca }\end{array}$ \\
\hline 14 & Arecaceae & Syagrus romanzoffiana & $\mathrm{H}$ & Ortalis squamata \\
\hline 19 & Cactaceae & Cereus hildmannianus & M & Birds (no specific mention) \\
\hline 20 & Cannabaceae & Celtis iguanaea & $\mathrm{H}$ & Penelope obscura, O. squamata \\
\hline 21 & Cannabaceae & Trema micranta & $\mathrm{H}$ & Mimus saturninus, Turdus spp., T. preciosa, \\
\hline 28 & Ebenaceae & Diospyros inconstans & $\mathrm{H}$ & P. obscura, O. squamata \\
\hline 30 & Erythroxylaceae & Erythroxylum argentinum & $\mathrm{H}$ & Birds (no specific mention) \\
\hline 38 & Euphorbiaceae & Gymnanthes klotzschiana & M & $\begin{array}{l}\text { Columbina picui, Zenaida auriculata, } \\
\text { Leptotila verreauxi }\end{array}$ \\
\hline 48 & Lamiaceae & Vitex megapotamica & $\mathrm{H}$ & P. obscura, O. squamata \\
\hline 49 & Lamiaceae & Nectandra megapotamica & M & Birds (no specific mention) \\
\hline 50 & Lauraceae & Ocotea puberula & $\mathrm{H}$ & P. frontalis \\
\hline 53 & Melastomataceae & Miconia hiemalis & $\mathrm{H}$ & Birds (no specific mention) \\
\hline 54 & Melastomataceae & Miconia pusilliflora & M & Birds (no specific mention) \\
\hline 55 & Meliaceae & Cabralea canjerana & M & P. obscura, O. squamata, Ramphastos spp. \\
\hline 59 & Moraceae & Ficus cestrifolia & M & Turdus spp., M. monachus, \\
\hline 60 & Moraceae & Ficus luschnathiana & $\mathrm{H}$ & Chiroptera, D. albiventris, C. paca \\
\hline 61 & Moraceae & Sorocea bonplandii & M & P.obscura, O. squamata, \\
\hline 62 & Myrtaceae & Acca sellowiana & $\mathrm{H}$ & $\begin{array}{l}\text { T. preciosa, D. albiventris, Dasypus } \\
\text { novemcinctus }\end{array}$ \\
\hline 63 & Myrtaceae & Blepharocalyx salicifolius & $\mathrm{H}$ & $\begin{array}{l}\text { Amazona pretrei, P. frontalis, P.obscura, } \\
\text { O. squamata }\end{array}$ \\
\hline 64 & Myrtaceae & $\begin{array}{l}\text { Campomanesia } \\
\text { xanthocarpa }\end{array}$ & M & $\begin{array}{l}\text { D. novemcinctus, D. albiventris, Cerdocyon } \\
\text { thous, Sphiggurus villosus, P.obscura, } \\
\text { O. squamata, C. caeruleus }\end{array}$ \\
\hline 65 & Myrtaceae & Eugenia involucrata & M & P. obscura \\
\hline 67 & Myrtaceae & Eugenia uniflora & $\mathrm{H}$ & $\begin{array}{l}\text { D. novemcinctus, D. albiventris, fish } \\
\text { (no specific mention) }\end{array}$ \\
\hline 73 & Myrtaceae & Myrcianthes pungens & $\mathrm{H}$ & P.obscura, O. squamata \\
\hline 74 & Myrtaceae & $\begin{array}{l}\text { Myrrhinium } \\
\text { atropurpureum }\end{array}$ & M & Birds (no specific mention) \\
\hline 75 & Myrtaceae & Psidium cattleianum & $\mathrm{H}$ & P. obscura, D. novemcinctus \\
\hline 79 & Podocarpaceae & Podocarpus lambertii & M & Birds (no specific mention) \\
\hline 82 & Primulaceae & Myrsine coriacea & M & P.obscura, O. squamata, Turdus spp. \\
\hline 84 & Primulaceae & Myrsine umbellata & $\mathrm{H}$ & Turdus sp., P. obscura, O. squamata \\
\hline 92 & Rutaceae & Zanthoxylum fagara & M & Birds (no specific mention) \\
\hline 97 & Salicaceae & Casearia sylvestris & M & T. preciosa, Pipraeidea bonariensis \\
\hline 100 & Sapindacea & Allophylus edulis & $\mathrm{H}$ & $\begin{array}{l}\text { P. obscura, O. squamata, Turdus sp., } \\
\text { C. caeruleus, T. preciosa }\end{array}$ \\
\hline 101 & Sapindacea & Cupania vernalis & M & Turdus spp., Rhamdia quelen \\
\hline 109 & Solanaceae & Vassobia breviflora & $\mathrm{H}$ & P. frontalis \\
\hline 114 & Verbenaceae & $\begin{array}{l}\text { Citharexylum } \\
\text { montevidense }\end{array}$ & $\mathrm{H}$ & $\begin{array}{l}\text { P. obscura, O. squamata, C. caeruleus, } \\
\text { Patagioenas picazuro, Ramphastos spp., } \\
\text { P. frontalis }\end{array}$ \\
\hline
\end{tabular}


Table 3. Tree species reported by family farmers in Serra dos Tapes (RS) and classified for environmental and ecosystem services for honey production.

\begin{tabular}{|c|c|c|}
\hline $\begin{array}{c}\text { Medium Relevance for Apis } \\
\text { melifera }\end{array}$ & High relevance for $A$. melifera & Reported for Apidae meliponini \\
\hline 01 - Sambucus australis & 02 - Lithrea brasiliensis & 14 - Syagrus romanzoffiana \\
\hline 05 - Schinus polygamus & 04 - Schinus molle & 30 - Erythroxylum argentinum \\
\hline 16 - Moquiniastrum polymorphum & 31 - Escallonia bifida & 31 - Escallonia bifida \\
\hline 38 - Gymnanthes klotzschiana & 35 - Manihot grahamii & 41 - Bauhinia forficata \\
\hline 49 - Nectandra megapotamica & 41 - Bauhinia forficata & 42 - Calliandra tweedie \\
\hline 53 - Miconia hiemalis & 48 - Vitex megapotamica & 47 - Senna corymbosa \\
\hline 64 - Campomanesia xanthocarpa & 52 - Luehea divaricata & 53 - Miconia hiemalis \\
\hline 67 - Eugenia uniflora & 93 - Zanthoxylum rhoifolium & 67 - Eugenia uniflora \\
\hline 68 - Eugenia uruguayensis & & 93 - Zanthoxylum rhoifolium \\
\hline \multicolumn{3}{|l|}{87 - Scutia buxifolia } \\
\hline \multicolumn{3}{|l|}{92 - Zanthoxylum fagara } \\
\hline \multicolumn{3}{|l|}{94 - Banara parviflora } \\
\hline \multicolumn{3}{|l|}{96 - Casearia decandra } \\
\hline \multicolumn{3}{|l|}{103 - Matayba elaeagnoides } \\
\hline 105 - Chrysophyllum marginatum & & \\
\hline
\end{tabular}

into ecosystem services essential for the maintenance of agricultural productivity". This subject is of great relevance for the impacts it may represent for future generations. Concerns over the death of bees are increasingly prevalent due to their role for agricultural crops (Potts et al., 2010).

Two species can be highlighted, Aroeira-preta (Lithrea brasiliensis) and Tarumã-branco (Vitex megapotamica), which were considered of high relevance as both honey plants and for feeding the fauna. In addition to its functionality for feeding the fauna and as honey plants, other tree species were mentioned for other ecosystem services, such as "holding slopes", protecting inclines and retaining barriers, such as the Sarandi (Terminalia australis), Quebra-foice (Calliandra tweedii), Corticeira (Erythrina cristagalli), Salso (Salix humboldtiana) and Mata-olho (Pouteria salicifolia).

In the environmental services, several examples were recognized by farmers as being offered by the regional tree flora, as in the case of species mentioned for use as "living fences", such as the Schinus terebinthifolia, Salix humboldtiana, and Cabralea canjerana. Some are used to improve soil quality and as green manure: Trema micrantha, Sapium glandulosum, Senna corymbosa, Quillaja brasiliensis, Solanum mauritianum and Vassobia breviflora.

Thirteen (13) species were reported for their multifunctionality in agroforestry systems as providers of environmental services: Lithrea brasiliensis, Schinus molle, Schinus terebinthifolia, Trema micrantha, Sapium glandulosum, Senna corymbosa, Luehea divaricata, Cabralea canjerana, Cedrela fissilis, Campomanesia xanthocarpa, Quillaja brasiliensis, Allophylus edulis and Solanum mauritianum.

The farmers revealed great knowledge about the role of trees in the agro-ecosystems.

Nowadays I see that trees are of vital importance to the farm, not only as firewood or for construction. They are part of the environment and without them, I would not be able to do my job... 19 years after having inserted the ecological production system, we can see several signs that nature is manifesting, complementing my production system.

In many cases, the adoption of agro-ecological formats, now common in the region (Cicconeto \& Verdum, 2012), were of great importance:

With the change to agroforestry systems, with the use of native species and black wattle, the plants of yerba mate are now appearing in the system, in the natural form of repopulation. The birds are planting the seeds for me.... capororoca, bugrinho, catiguá, tarumã-de-espinho, caixeta, batinga... (Informant 1).

A great diversity of species serving as food for animals and people, resulting in well-preserved springs. (Informant 2).

A variety of trees and animals, and the soil is fertile. The conditions of the soil are very important and will determine the presence and age of the plants. If there are plants in the water streams and in the springs, that avoids erosion. (Informant 3). 
The vegetation has to be very diverse, with many birds, signs of animals, dung, footprints. Lichens on the trees and mushrooms degrading the trunks. The smell after the rain is the same as the forest with life. Signs that it is moist, alive. And whoever realizes it feels integrated in that atmosphere, feels part of it: This is my house! (Informant 4).

\section{CONCLUSION}

The interviewed family farmers have vast knowledge about the characteristics, uses, and functionalities of the native tree species of Serra dos Tapes. This knowledge allows them to clearly and objectively identify ecosystem services related to avifauna, pollinators and honey species, in addition to others related to the preservation of riparian forests (protection of ravines, slopes, and barriers). Farmers also demonstrated wisdom in using the environmental services offered to qualify and diversify their production systems. Several species are used as living fences, as green manure, to improve soil quality, add value and even diversify food. Management of Agroforestry Systems with the use of complementary species that provide ecosystem and environmental services qualifies the production systems. The farmers' knowledge regarding the characteristics, uses, and functionalities of the species offers subsidies for recovery programs and environmental adequacy in compliance with the Forest Code, indicating species for recovery of degraded areas, preservation of protected areas and qualification of production systems.

\section{SUBMISSION STATUS}

Received: 14 june, 2016

Accepted: 21 nov., 2017

\section{CORRESPONDENCE TO}

\section{Gustavo Crizel Gomes}

Programa de Pós-graduação em

Desenvolvimento Territorial e Sistemas

Agroindustriais, Universidade Federal de Pelotas

- UFPel, Av. Eliseu Maciel, s/n, Capão Leão,

CEP 96001-970, Pelotas, RS, Brasil

e-mail: crizelgomes@gmail.com

\section{REFERENCES}

Albuquerque UP, Lucena RFP, Alencar NL. Métodos e técnicas para coleta de dados etnobiológicos. In: Albuquerque UP, Lucena RFP, Cunha LVFC. Métodos e técnicas na pesquisa etnobiológica e etnoecológica. 1. ed. Recife: Nupeea; 2010. p. 46-47.

Almeida DS. Recuperação ambiental da Mata Atlântica. Ilhéus: Editus; 2000.

Andrade DC, Romeiro AR. Serviços ecossistêmicos e sua importância para o sistema econômico e o bem-estar humano. Campinas: IE/UNICAMP; 2009. (Texto para Discussão; no. 155).

Angiosperm Phylogeny Group - APG IV. An update of the Angiosperm Phylogeny Group classification for the orders and families of flowering plants: APG IV. Botanical Journal of the Linnean Society 2016; 181(1): 1-20. http:// dx.doi.org/10.1111/boj.12385.

Azpiroz A. Aves de las pampas y campos de Argentina, Brasil y Uruguay: una guía de identificación. Nueva Helvecia: Pressur; 2012.

Barbieri RL, Gomes JCC, Alercia A, Padulosi S. Agricultural biodiversity in southern Brazil: integrating efforts for conservation and use of neglected and underutilized species. Sustainability 2014; 6(2): 741-757. http://dx.doi. org/10.3390/su6020741.

Belton W. Aves silvestres do Rio Grande do Sul. 4. ed. Porto Alegre: Fundação Zoobotânica do Rio Grande do Sul; 2004.

Bernard HR. Research methods in anthropology: qualitative and quantitative approaches. London: Rowman Altamira; 2011.

Brasil. Ministério da Saúde. Conselho Nacional de Saúde. Resolução $n^{\circ} 196$ de 10 de out. de 1996. Estabelece diretrizes e normas regulamentadoras da pesquisa envolvendo seres humanos [online]. Diário Oficial da República Federativa do Brasil, Brasília, DF (1996 out. 16). [cited 2016 June 14]. Available from: http://conselho.saude.gov.br/resolucoes/ reso_96.htm

Brasil. Lei $n^{\circ}$ 13.123, de 20 de maio de 2015. Dispóe sobre o acesso ao patrimônio genético, sobre a proteção e $o$ acesso ao conhecimento tradicional associado e sobre a repartição de benefícios para conservação e uso sustentável da biodiversidade [online]. Diário Oficial da República Federativa do Brasil, Brasília, DF (2015 maio 21). [cited 2016 June 14]. Available from: http://conselho.saude.gov. br/resolucoes/reso_96.htm

Cavalcanti C. Concepções da economia ecológica: suas relações com a economia dominante e a economia ambiental. Estudos Avançados 2010; 24(68): 53-67. http:// dx.doi.org/10.1590/S0103-40142010000100007.

Cicconeto J, Verdum R. Agricultura familiar ecológica em Canguçu (RS): trajetórias e perspectivas. Redes 2012; 17(3): 99-121. 
Develey PF, Pongiluppi T. Impactos potenciais na avifauna decorrentes das alterações propostas para o Código Florestal Brasileiro. Biota Neotropica 2010; 10(4): 43-46. http://dx.doi.org/10.1590/S1676-06032010000400005.

Elias GA, Santos R. Produtos florestais não madeireiros e valor potencial de exploração sustentável da Floresta Atlântica no sul de Santa Catarina. Ciência Florestal 2016; 26(1): 249-262. http://dx.doi.org/10.5902/1980509821117.

Filgueiras TS, Nogueira PE, Brochado AL, Guala GF 2nd. Caminhamento: um método expedido para levantamentos florísticos qualitativos. Cadernos de Geociência 1994; 12: $39-43$.

Galetti M, Pardini R, Duarte JMB, Silva VMS, Rossi A, Peres CA. Mudanças no Código Florestal e seu impacto na ecologia e diversidade dos mamíferos no Brasil. Biota Neotropica 2010; 10(4): 47-52. http://dx.doi.org/10.1590/ S1676-06032010000400006.

Gomes GC. Composição e aspectos ecológicos da flora arbustivo-arbórea nativa da serra dos Tapes Pelotas [dissertação]. Pelotas: Universidade Federal de Pelotas; 2009.

Gomes GC. As árvores nativas e o saber local como contribuição à sustentabilidade de agroecossistemas familiares na Serra dos Tapes, RS [tese]. Pelotas: Universidade Federal de Pelotas; 2014.

Gonçalves GL, Quintela FM, Freitas TRO. Mamíferos do Rio Grande do Sul. Porto Alegre: Pacartes; 2014.

Imperatriz-Fonseca VL, Nunes-Silva P. As abelhas, os serviços ecossistêmicos e o Código Florestal Brasileiro. Biota Neotropica 2010; 10(4): 59-62. http://dx.doi.org/10.1590/ S1676-06032010000400008.

Instituto Nacional de Colonização e Reforma Agrária INCRA. Instrução especial/INCRA n ${ }^{\circ} 20$, de 28 de maio de 1980. Estabelece o módulo fiscal de cada município, previsto no Decreto $n^{\circ} 84.685$ de 06 de maio de 1980. Aprovado pela Portaria/MA 146/80 [online]. Diário Oficial da República Federativa do Brasil, Brasília, DF (1980 jun. 12). [cited 2017 May 23]. Available from: http://www.incra.gov.br/ media/institucional/legislacao/atos_internos/instrucoes/ instrucao_especial/IE20_280580.pdf

Jurinitz CF. Estrutura do componente arbóreo de uma floresta estacional na Serra do Herval, Sul do Brasil [dissertação]. Porto Alegre: Universidade Federal do Rio Grande do Sul; 2002.

Kangas P. Tropical sustainable development and biodiversity. In: Reaka Kudla ML, Wilson DE, Wilson EO, editors. Biodiversity II: understanding and protecting our biological resources. Washington: Joseph Henry, 1997. p. 389-398.

Kilca RV. Alguns aspectos florísticos e estruturais de uma floresta de galeria no sul da planície costeira do Rio Grande do Sul [monografia]. Pelotas: Universidade Federal de Pelotas; 2002.

Manzini EJ. Entrevista semi-estruturada: análise de objetivos e de roteiros [online]. Marília: Programa de
Pós-graduação em Educação, Departamento de Educação Especial, Universidade Estadual São Paulo; 2004. [cited 2017 May 23]. Available from: http://www.sepq.org.br/ IIsipeq/anais/pdf/ gt3/04.pdf

Martinez E, Lima AC, Casalinho H, Silva D, Winckel T. Serviços Ambientais ofertados por diferentes agroecossistemas de base familiar no Território Zona Sul do RS. Cadernos de Agroecologia [online] 2013; 8(2). [cited 2017 May 23]. Available from: http://www.aba-agroecologia.org.br/ revistas/ index.php/cad/article/view/13606/8934

Mikhailova I, Barbosa FAR. Valorando o capital natural e os serviços ecológicos de unidades de conservação: o caso do Parque Estadual do Rio Doce-MG, Sudeste do Brasil. Belo Horizonte: UFMG/Cedeplar; 2004. (Texto para Discussão; no. 230).

Potts SG, Biesmeijer JC, Kremen C, Neumann P, Schweiger O, Kunin WE. Global Pollinator declines: trends, impacts and drives. Trends in Ecology and Evolution 2010; 25(6): 345-353. http://dx.doi.org/10.1016/j.tree.2010.01.007. PMid:20188434.

Reichert L, Gomes JCC. A produção agroecológica como estratégia de segurança e soberania alimentar na agricultura familiar. Cadernos de Agroecologia [online] 2013; 8(2). [cited 2017 May 23]. Available from: http:// www.aba-agroecologia.org.br/revistas/index.php/cad/ article/view/14405/9028

Rodrigues DM, Silva MM, Almeida LS, Souza JTR, Yared JAG, Santana AC. Agrobiodiversidade e os serviços ambientais: perspectivas para o manejo ecológico dos agroecossistemas no estado do Pará. Agroecossistemas 2012; 4(1): 12-32. http://dx.doi.org/10.18542/ragros.v4i1.1047.

Rodrigues WF, Gomes GC, Medeiros ARM, Barbieri RL. Espécies arbóreas da Serra dos Tapes: um resgate etnobotânico. Pelotas: Embrapa Clima Temperado; 2007. (Documentos; no. 190). [cited 2017 May 23]. Available from: http://www.infoteca.cnptia.embrapa.br/handle/ doc/745873

Roman C, Weber M M, Cáceres NC. Mamíferos do Rio Grande do Sul. Santa Maria: UFSM; 2013.

Simões LL, Lino CF, editors. Sustentável Mata Atlântica: a exploração de seus recursos florestais. 2. ed. São Paulo: SENAC; 2002.

Sobral MEG, Jarenkow JA, Brack P, Irgang BE, Larocca J, Rodrigues RS. Flora arbórea e arborescente do Rio Grande do Sul, Brasil. São Carlos: Rima e Novo Ambiente; 2006.

Souza CA. Estrutura do componente arbóreo de floresta pluvial subtropical na Serra dos Tapes, sul do Rio Grande do Sul [dissertação]. Porto Alegre: Universidade Federal do Rio Grande do Sul; 2001.

Teixeira MB, Coura AB No, Pastore U, Rangel ALR Fo. As regióes fitoecológicas, sua natureza e seus recursos econômico: estudo fitogeográfico. Rio de Janeiro: Instituto 
Brasileiro de Geografia e Estatística; 1986. p. 541-632. (Série Levantamento de Recursos Naturais; no. 33).

Tôsto SG, Pereira LC, Mangabeira JAC. Serviços ecossistêmicos e Serviços ambientais: conceitos e importância [online]. Rio de Janeiro: Portal Ecodebate; 2012. [cited 2016 June 14]. Available from: http://www.ecodebate.com.br/2012/12/13/ servicos-ecossistemicos-e-servicos-ambientais-conceitose-importancia-artigo-de-sergio-gomes-tosto-lauro-charletpereira-e-joao-alfredo-de-c-mangabeira/

Venzke TS. Florística, estrutura e síndrome de dispersão de sementes em estágios sucessionais da mata ciliar no município de Arroio do Padre, RS, Brasil [dissertação]. Viçosa: Universidade Federal de Viçosa; 2012.
Vieira V, Quoos JH, Verdum R. Compartimentos morfopedogênicos: potencialidades e limites na sustentação dos sistemas de cultivo e criação no município de Canguçu - RS, Brasil. Para Onde 2011; 5(1).

Whately M, Hercowitz M. Serviços ambientais: conhecer, valorizar e cuidar: subsídios para a proteção dos mananciais de São Paulo. São Paulo: Instituto Socioambiental; 2008.

Wolff LF, Gomes JCC. Beekeeping and agroecological systems for endogenous sustainable development. Agroecology and Sustainable Food Systems 2015; 39(4): 416-435. http://dx.doi.org/10.1080/21683565.2014. 991056. 